\title{
Real Estate Fund Openings and Cannibalization
}

\author{
This version: July 31, 2015
}

\begin{abstract}
This paper examines the trade-offs in launching new real estate funds, specifically open-end, direct-property funds. This investment vehicle, which is designed to provide the risk-return benefits of private market real estate, is available to retail investors in a number of countries. At the same time, these funds are also subject to liquidity risk, because they hold an inherently illiquid asset in an open-end structure. This format presents fund-family managers with unique challenges, particularly with the decision to opening new funds. The data consists of 2,127 German fund openings across 76 fund families in 12 asset classes over the 1992-2010 period. Including a wide range of asset classes allows for a comparison of real estate and other investment objectives. We find a substantial cannibalization effect across the existing real estate funds of a family, while we note the opposite effect - i.e., flows into existing funds increase following a fund opening within the same objective - for all other asset classes. Our analysis of fund opening determinants shows that inflows mitigate the cannibalization risk for new real estate funds. Additional evidence highlights the role of scale and scope economies in real estate fund openings. Overall, the results provide new insights into the relatively large size and small number of real estate funds when compared to mutual funds dedicated to other investment objectives.
\end{abstract}

Key words: Real Estate, Fund Flows, Fund Openings, Cannibalization JEL classification: G11, G17, G29 


\section{Introduction}

Mutual fund families compete based on performance and breadth of fund offerings. Opening a new fund can affect both of these dimensions at the same time. Each fund opening increases the likelihood that one of a family's funds will exhibit superior investment performance while it also leads to an expansion of the product line. Another advantage of fund openings is documented by Khorana and Servaes (1999), who find that fund families recognize economies of scale and scope by opening new funds. Empirical support for the profitability of fund openings comes from Khorana and Servaes (2012), who find that fund openings lead to higher market share. Given these advantages, the frequent use of fund openings is not surprising. Evans (2010) documents that fund families even incubate mutual funds, that is, they open several funds privately, and at the end of the incubation period offer only the best performing funds to the public. The resulting large number of mutual funds in the industry has been described by some scholars as excessive (Massa, 2000). In this paper, we examine these issues for open-end, direct-property funds - a specific type of mutual fund which may face much different challenges than typical mutual funds.

Considering the trade-offs, openings may also lead to fund flow cannibalization when the growth of new funds comes at the cost of a family's existing funds. While the positive effect of fund openings on the market share of the family implies that the inflows achieved through fund openings outweigh a potential cannibalization effect, the mutual fund literature lacks a systematic analysis of how fund flows into existing funds are affected by new fund openings of the family. The risk of self-inflicted liquidations of portfolio positions is particularly relevant for funds investing in illiquid asset classes such as real estate. Here, disinvestments can be characterized by high costs and long transaction periods. However, funds focused on less liquid stocks or bonds may also be negatively affected by fund openings. Ultimately, the potential cost of cannibalization must be considered for fund openings within specific investment objectives.

The goal of this paper is to study the trade-offs associated with opening new real estate funds. Germany ranks as the largest and most developed real estate fund industry for individual investors; hence, we concentrate our analysis on German 
mutual fund data. The notion of a direct-property, open-end mutual fund (hereinafter referred to as a real estate fund), intended for individual investors, may be somewhat foreign to some readers and even real estate investment scholars, because that fund type is not available in the U.S. ${ }^{1}$

German real estate funds can be understood as a compromise between direct investment in private real estate and listed real estate (e.g., publicly traded REITs), the latter of which offers liquidity. The underlying assets of German real estate funds and their counterparts globally - are direct-property investments. ${ }^{2}$ Given the relative illiquidity of real estate as an underlying asset in an open-end fund format, fund-level liquidity is of particular interest. To maintain daily liquidity (i.e., offer daily share redemptions), German real estate funds typically hold high cash reserves. Real estate fund returns are derived from the fund's NAV per share, which is reported on a daily basis and depends predominantly on appraisal-based property values. The NAVbased pricing scheme results in a risk-return profile that is comparable to appraisalbased, private-market real estate indices (such as NPI, the NCREIF Property Index). Diversification and low volatility are a primary appeal of this investment vehicle, and have contributed to its continuing popularity in many countries. ${ }^{3}$

Despite the benefits, however, the financial intermediation offered through openend, direct-property funds is not perfect. For example, if a fund runs low on cash

\footnotetext{
1 The U.S. real estate investment vehicle that comes closest to German open-end real estate funds is a "commingled" real estate fund. Those included in the NFI-OE (the NCREIF Fund Index - OpenEnd Equity), for example, invest in direct property and have an open-end fund structure. However, these funds are operated for and are restricted to institutional investors. U.S. retail investors can only gain exposure through defined contribution plans or other sponsor-type relationships. Retail investors in the U.S. and many other countries typically gain exposure to real estate by investing in REITs or REIT mutual funds. U.S.-domiciled REIT mutual funds are only similar to German real estate funds in that both investment vehicles share an open-end format. U.S. REIT mutual funds are known for investing in securities such as mortgage-backed bonds or REIT shares. Similarly to German real estate funds, Equity REITs - which are not open-end funds but are more analogous to closed-end funds - invest in direct property. For some retail investors, direct real estate may be accessed through non-traded REITs, but these are closed-end vehicles that are not comparable to the German experience.

${ }^{2}$ See the Appendix for a list of countries in which open-end, direct-property funds are available to retail investors.

${ }^{3}$ For example, recent global evidence finds that optimal multi-asset portfolios devote large shares to direct real estate (e.g. Rehring, 2012). MacKinnon and Al Zaman (2009) find that REITs are a redundant asset class for investors with access to direct real estate. Schweizer, Haß, Johanning, and Rudolph (2011) compare REITs and German real estate funds in a multi-asset portfolio context, and show that real estate funds have a diversification advantage over REITs in low-risk portfolios.
} 
reserves, share redemptions may be temporarily suspended, and the fund may become illiquid. ${ }^{4}$ We thus caution readers to interpret our results with these caveats in mind. The following section analyzes how the tension between fund-level liquidity and the underlying asset liquidity affects the real estate fund opening decision. The Appendix provides additional background and some institutional details on the global mutual fund market, open-end real estate funds, and, specifically, the German real estate fund industry.

Our objective is to examine 1) the implications of fund flow cannibalization, and 2 ) the determinants of fund openings, both with a focus on real estate funds. Our analysis is motivated by the fact that open-end, direct-property funds are typically allowed to grow much larger and are started less frequently than funds dedicated to other investment objectives. Thus far, the fund opening literature has focused on investment objectives defined by liquid asset classes (e.g., stocks and bonds). To our knowledge, this is the first study that addresses real estate fund openings. Including other asset classes in the analysis enables us to compare real estate and alternative investment objectives. Our sample consists of a panel of 76 fund families that could potentially open funds in 12 asset classes over the 1992-2010 period. Overall, we observe 2,127 German fund openings across all investment objectives.

The first part of our study proposes a novel and direct test of cannibalization by analyzing whether and to what extent fund flows into existing funds in the same family within an investment objective are affected by new fund openings. To isolate the cannibalization effect, we control for further variables that may affect fund flows within the family-objective level. These include the lagged returns of the family's funds within the investment objective, aggregate fund flows into the family within the investment objective, size of the fund family, percentage of family assets invested in the investment objective, and total number of fund openings within the investment objective. To determine whether cannibalization is a real estate-specific effect, we interact the number of funds opened by the family with a dichotomous variable for real estate funds. The parameters are estimated using a generalized method of moments (GMM) approach.

\footnotetext{
${ }^{4}$ See, e.g., Weistroffer and Sebastian (2014) for a description of the German experience.
} 
The empirical analysis reveals a substantial cannibalization effect subsequent to a real estate fund opening. The opening of a new real estate fund is, on average, associated with a reduction of 438 million Euros of fund flows into existing real estate funds of the family. In contrast, fund openings have a moderately positive effect on fund flows into existing funds in all other investment objectives, suggesting that cannibalization is a real estate-specific phenomenon.

The second part of our study analyzes the determinants of fund openings, again with an emphasis on real estate-specific determinants. Several characteristics of direct real estate investments suggest that these determinants may differ from those of other asset classes. For example, the combination of cannibalization risk and the illiquidity of the asset class may lead to a more pronounced role of liquidity in fund family decisions. Furthermore, the fact that direct real estate is indivisible may hinder the construction of diversified portfolios. Prior to opening a new real estate fund, there may thus be an incentive to allow existing real estate funds to grow large relative to other asset class funds. The heterogeneity of real estate investments - relative to other asset classes - may also prevent the fund family from benefiting from economies of scale and scope through real estate fund openings.

We use probit regression techniques to examine the determinants of real estate fund openings and how they differ from fund openings in all other investment objectives. Our probit regression models have standard errors clustered at the level of the fund family, and time fixed effects. The dependent variable is binary, and indicates whether or not a fund family has opened a new fund within a specific investment objective.

The set of explanatory variables consists of fund flows into existing funds of the family within an investment objective in order to test whether fund openings are liquidity-driven. We examine the role of economies of scale and scope in fund openings through the variables family size, fraction of family assets invested in an investment objective, and number of funds opened by the family in the prior year. We use the excess return of the funds in a family's investment objective to test whether fund openings are driven by return considerations. We also include industry-level control variables. To test our real estate-specific hypotheses, we interact the respective 
explanatory variable with a dichotomous variable. This variable indicates whether the fund opening (or non-opening) occurs within the real estate investment objective.

We find evidence that real estate fund openings are liquidity-driven. When the real estate funds of the family experience high outflows, the real estate fund opening probability goes to zero. In contrast, high inflows into the existing real estate funds of the family strongly increase the real estate fund opening probability. This flow dependence is much weaker for fund openings in all other investment objectives, which suggests that fund families are only willing to bear the risk of cannibalization if high inflows compensate for expected outflows. Furthermore, the proxies for economies of scale and scope in fund openings indicate they play only a minor role in real estate fund openings. However, they are strong drivers of fund openings in all other asset classes.

Overall, our results suggest that the determinants of real estate fund openings cannot be subsumed under a general fund opening framework. To the contrary, the economic principles underlying the real estate fund opening decision are asset classspecific. This paper is therefore the first to document this finding, as well as the fundamental influence that cannibalization plays in real estate fund openings.

The remainder of this paper is organized as follows. The next section reviews the related literature, and develops testable implications of the effects and determinants of real estate fund openings. Afterward, we introduce the data and methodology. The empirical results section follows. The final section offers our conclusions. The Appendix provides additional background on open-end, direct-property funds, as well as on the German mutual fund industry.

\section{Related Literature and Hypotheses}

\subsection{Fund Openings - Benefits and Costs}

As profit-oriented companies, fund families strive to increase their firm value. The principal driver of fund family value is an increase in assets under management (AuM). The mutual fund literature finds that fund families strategically compete in their marketplace through fund performance and the breadth of their offerings. Fund 
openings play an important role in this context, because fund families can affect both dimensions at the same time by opening a new fund.

Top-performing mutual funds not only attract disproportionately high inflows for themselves (Sirri and Tufano, 1998), but also for the other funds of the family (Nanda, Wang, and Zheng, 2004). Accordingly, it makes sense for fund families to increase their chances of having a highly ranked fund by opening new funds. Goetzmann and Ibbotson (1993) hypothesize that this probability is maximized when the fund family opens many funds simultaneously with a low correlation between the investment strategies. Nanda, Wang, and Zheng (2004) confirm that families with a higher variation in investment strategies across funds are more likely to generate star performers.

The widespread implementation of this practical strategy is documented by Evans (2010), who finds that fund families incubate mutual funds. He finds that fund families tend to open several funds privately, and, at the end of the incubation period, offer only the best-performing funds to the public. Fund families may also open new funds as a way to window-dress the poor performance of existing funds. Berzins (2005) finds that low-skill families, which fail to attract new money due to prior poor performance, can successfully regain cash flows by opening new funds.

Fund families also aim to increase their product line and thereby appeal to a broader range of investors by opening new funds. Massa (2000) argues that fund families exploit the heterogeneity of investors by offering various funds in diverse investment categories. Massa (2003) goes on to find that fund openings enable fund families to compete less on performance when they are able to differentiate themselves along non-performance-related fund characteristics.

When a new fund is opened, it either represents a new investment style, or it follows current industry trends. Khorana and Servaes (1999) find that fund families follow industry leaders by attempting to replicate their fund opening decisions.

However, following industry trends may also be accomplished if fund families simply change the names of existing funds. Cooper, Gulen, and Rau (2005) find that fund families have taken successful advantage of current hot investment styles by changing fund names. They report a $28 \%$ average cumulative inflow without any concurrent performance improvement. The introduction of multiple share classes of 
the same investment portfolio is another option for fund families to address investor heterogeneity. Nanda, Wang, and Zheng (2009) find that especially large fund families are more likely to benefit from and switch to a multiple share class structure.

Based on the benefits of fund openings, we would expect fund families to exhibit a propensity to open new funds regardless of investment objective. However, there are costs associated with new fund openings, such as initial marketing, organizational, and ongoing operating costs. However, these costs are lower on a per unit basis when fund families can benefit from economies of scale. Hence, the propensity to open a new fund may also depend on the potential of the fund family to benefit from economies of scale and scope. Khorana and Servaes (1999) find that economies of scale and scope are actually an important determinant of fund openings. They document a higher fund opening probability for larger and more experienced fund families.

In summary, fund families will open new funds when the expected benefits outweigh the anticipated costs. This cost-benefit trade-off may differ for real estate funds when compared to other asset classes. For example, fund flow cannibalization of existing funds through new fund openings is of particular concern with real estate funds because of the illiquidity of the underlying assets. We next provide a closer look at cannibalization, and develop testable hypotheses regarding the differences in real estate fund openings versus all other asset classes.

\subsection{Cannibalization}

New mutual funds are generally advertised heavily during their introduction phase. As a result of focused marketing efforts by the fund family, new funds may simply grow at the cost of existing funds, and they may even "steal" flows from existing funds. If existing funds fail to retain AuM or attract new investor money, they may be forced to liquidate portfolio positions in order to pay investors who wish to redeem shares. This raises two questions: 1) Is the overall effect of fund openings positive, and are the inflows into new funds offset by outflows from the existing funds of the family? and 2) are flows into existing funds of the family cannibalized through new fund openings, and to what extent? 
Khorana and Servaes (1999) find that fund openings are more likely to occur in investment objectives in which the fund family is more strongly represented. They thus conclude that the benefits of specialization are likely to outweigh the costs of cannibalization. Khorana and Servaes (2012) also document that fund openings positively affect the fund family's market share, and they conclude that cannibalization of existing funds is not a significant problem. The literature provides considerable evidence that the overall effect of fund openings is positive. At the same time, these studies have not addressed the more specific issue of cannibalization. Thus, the second question remains to be answered.

In a working paper version of their study, Nanda, Wang, and Zheng (2009) conduct a test of cannibalization at the individual fund level by examining whether new share classes negatively affect fund flows into the existing share class of the same investment portfolio. They find no evidence of cannibalization for the A class by other share classes. To our knowledge, no published study has provided a direct test of cannibalization through new fund openings at the level of the fund family. We formulate our cannibalization hypothesis of fund openings as follows:

Hypothesis 1: Cannibalization of fund flows occurs subsequent to a fund opening within a given family (i.e., the family's fund opening has a negative impact on subsequent fund flows).

\subsection{Liquidity}

As we have noted, real estate funds are particularly subject to liquidity risk. Unlike REITs, where management is relatively free to distribute or raise capital to exploit market opportunities (Boudry, Kallberg, and Liu, 2010), net flows into or out of real estate funds depend on the buying and selling decisions of individual investors or institutions. This is not as problematic for equity and fixed income funds, because they can sell their underlying securities in a short period of time for relatively low transaction costs. However, for a real estate fund, a negative cash flow shock can be challenging because the disposition of direct property is time-consuming and expensive.

If cannibalization is an issue, the fund opening itself is a source of liquidity risk 
for existing real estate funds, while funds in liquid asset classes may remain unaffected. Fund families may thus consider cannibalization as a barrier to real estate fund openings.

However, the literature provides ample evidence that this liquidity risk can be significantly reduced or even eliminated. For example, Warther (1995) documents that aggregate fund flows are highly autocorrelated. This implies that current positive fund flows are likely to persist, which can attenuate a potential cannibalization effect. Fund families can also derive optimistic expectations about future fund flows from the state of the real estate market. Plazzi, Torous, and Valkanov (2010) find that direct-property returns are predictable. If rational investors exploit this predictability by increasing their allocations to real estate, an expected upswing in the real estate market could lead to positive net flows into real estate funds. When fund flows into existing funds are high, fund families may open a new fund to absorb the excess demand.

In contrast, persistence in outflows or an expected decline in the market can be seen as barriers to real estate fund openings. Funds investing in liquid asset classes are robust to negative cash flow shocks, so their fund opening probability should be unrelated (or less related) to fund flows. In fact, Khorana and Servaes (1999), whose sample is restricted to funds that invest in liquid asset classes, find no relationship between fund flows and fund opening probability. We test whether a positive relationship exists, which leads to our liquidity hypothesis for the determinants of real estate fund openings:

Hypothesis 2: The marginal effect of liquidity on real estate fund openings, relative to other asset classes, is positive.

\subsection{Economies of Scale and Scope}

Latzko (1999) finds that the average costs of mutual funds fall with fund size. It is not surprising that economies of scale and scope exist at the fund family level. Many sources of scale economies can be shared across funds, such as costs for research, marketing, and distribution, as well as efficiencies in securities transactions execution (e.g., Deli (2002) and Khorana, Servaes, and Tufano (2009)). This raises the question 
of whether large fund families, which may seem positioned to benefit from economies of scale and scope, are better served by having a few large funds, or a large number of small funds.

The mutual fund literature suggests that fund families actually prefer small funds over large ones. Deli (2002) finds that competitive pressures force fund families to pass economies of scale along to investors. However, the extent of these pressures remains debatable. If fund families can charge higher fees for small funds, then the same amount of AuM will generate more fee income when spread over many smaller funds. Chen, Hong, Huang, and Kubik (2004) finds that fund performance erodes with fund size, which provides another argument in favor of small funds. Consistent with this finding, Zhao (2004) documents that larger funds are more likely to be closed to new investors. Furthermore, fund families increase the probability of having a top performer by offering multiple small funds. Thus, large fund families have an incentive to open more funds in order to reduce the average size of existing funds. In fact, Khorana and Servaes (1999) find that larger families obtain a higher fund opening probability which is consistent with the view that fund families reap economies of scale and scope by opening more funds.

In contrast to the diseconomies of scale for mutual funds in general, the real estate literature provides (strong) evidence in favor of large real estate funds. Ambrose, Highfield, and Linneman (2005), for example, find economies of scale and scope for large REITs. Due to the general lumpiness and the indivisibility of direct real estate, large property-portfolios also tend to be more beneficial from a risk-return perspective.

Plazzi, Torous, and Valkanov (2008) document a positive relationship between the total risk and return of commercial property. They note that only systematic risk is priced in the equity markets, while idiosyncratic risk is also priced in the real estate market, because it cannot be diversified away. This implies that larger property-portfolios may earn superior risk-adjusted returns.

Another argument in favor of large real estate funds comes from Eichholtz, Koedijk, and Schweitzer (2001). They document the underperformance of international real estate companies when compared to domestic real estate companies. They posit that size appears to be the only factor that can improve the performance of global prop- 
erty portfolios, probably because only large international property companies can overcome the information disadvantages of covering multiple international markets. In addition, and for obvious reasons, the strategy of opening multiple real estate funds (i.e., incubating direct-property funds), in the hope of breeding a top performer is not feasible.

Finally, family-level economies of scale and scope achieved from fund openings are likely to be smaller for real estate in comparison to other investment objectives. The heterogeneity of real estate reduces the potential to standardize the processes associated with fund operation. For example, efficiencies in the execution of securities transactions make it easy for a fund family to expand to the money market sector when it already offers equity or fixed income funds. However, this does not hold for a potential expansion into the real estate fund business. The potential efficiencies with real estate transactions are completely different, due to the different requirements of operational real asset management (e.g., taxes, transactions).

As a result of the reduced economies of scope at the fund family level, and incentives to let existing real estate funds to grow large, we anticipate a muted effect for economies of scale and scope as determinants of real estate fund openings. Accordingly, we formulate our economies of scale and scope hypothesis of real estate fund openings as follows:

Hypothesis 3: The marginal effect of economies of scale and scope on real estate fund openings, relative to other asset classes, is negative.

\section{Data and Methodology}

\subsection{Data Sources}

Our empirical analysis is based on the German open-end mutual fund industry over the 1992-2010 period. We obtain fund opening dates, family membership, and investment category affiliation from a survivorship bias-free sample of the German Investment and Asset Management Association (BVI). BVI members represent approximately 99 percent of the German mutual fund industry's AuM. The dataset also 
includes information on net flows into and the total size (i.e., AuM) of individual funds. Fund returns come from Morningstar and Datastream. Since fund families are sometimes split up into legally but not economically independent investment companies (KAGs), we group these together. Our final sample consists of 76 fund families that could potentially open new funds in 12 investment objectives, or asset classes, which we include in our study: real estate, equity, fixed income, money market, hedge funds, fund of funds, capital protected funds, management objective funds, balanced funds, life cycle funds, hybrid funds, and other funds.

Zhao (2005) stresses the importance of differentiating between the opening of a new investment portfolio, and the issuance of another share class for an already existing portfolio. Since our analysis focuses on actual extensions of a product line, as opposed to minimal modifications of existing products, we restrict our analysis to new portfolio openings. As such, we define a fund opening as any new investment portfolio opened by a fund family in a given year. If Morningstar characterizes a fund as the oldest share class, we include the fund opening in our sample. Otherwise, we consider the opening to be another share class of an existing portfolio.

In our sample of real estate fund openings, we focus on retail funds. We exclude semi-institutional funds, which are primarily intended for institutional investors. ${ }^{5}$

\subsection{The Sample of Real Estate Fund Openings}

Figure 1 shows the total number of fund openings by investment objective across the sample period, as well as the total AuM of the respective investment objective at the end of the sample period. The average AuM by investment objective is illustrated by the size of the bubble (i.e., circle). Although real estate represents the fourth largest investment objective, it accounts for less than one out of 100 fund openings. At the same time, the average size of a real estate fund is considerably larger than the size of other investment objective funds. This supports the view of strong fund-level

\footnotetext{
${ }^{5}$ We identify 12 semi-institutional fund openings in our sample. However, our findings are unchanged if we include these funds. The results are available upon request. At the same time, we argue that semi-institutional funds do not belong in our analysis. They are legally classified as retail funds, but the minimum investment begins at one million Euros. Consequently, semi-institutional funds do not fit the framework of our paper, where a fund family offers and manages a fund that is accessible to all investors.
} 
economies of scale for the real estate investment objective.

Table I shows the distribution of fund openings over the 1992-2010 period in each of the 12 investment objectives. The first column lists the number of funds in existence at the beginning of the sample period (297). A total of 2,127 funds are opened with substantial variation over time and investment objective. Thus, we observe that the German fund industry has experienced strong growth over the course of our sample period. The average number of new funds per year increased tenfold, from 26 in the first five years, to 256 in the last five years. Moreover, in 1992, the German mutual fund market was dominated by equity and fixed income funds; balanced, money market, and real estate funds played only a minor role. While most funds were opened in the equity investment objective (687), balanced funds (670) outgrew fixed income funds (312). And several new investment objectives emerged over the years, with capital protected funds (195) among the more significant groups. Combined fund openings in the remaining eight investment objectives account for $12.4 \%$ of all fund openings, with an average of 33 openings.

Most of the 17 real estate funds opened between 1997 and 2005. Almost all funds that opened prior to 2001 made use of a regulatory change that enabled German real estate funds to invest EU-wide without restrictions. Note that, prior to 1990, at least $80 \%$ of property portfolios were required to be invested in Germany. Since 2002, real estate funds have been permitted to invest globally, and nearly all new funds since then have done so.

This indicates that the real estate fund industry, like other investment objectives, is also subject to trends and fashions. Product heterogeneity is rather low. Each of the four largest fund families (industry leaders) has one European and one Global real estate fund. One family also has a third real estate fund with a German investment focus. We do not observe more than one real estate fund opening by the same family in a given year, which (intentionally or not) reduces cannibalization risks for existing real estate funds. Since 1992, seven fund families represented all the new entrants into the market. Nine fund families opened their second real estate fund, and one fund family opened its second and third real estate fund during the sample period. 


\subsection{Research Design and Variable Definitions}

We examine fund openings from two distinct perspectives. First, we analyze the relation between fund openings and the subsequent (i.e., ex post) inflows of existing funds within the family objective. This allows us to understand whether, and to what extent, cannibalization exists for existing funds. The second set of tests analyzes the determinants of fund openings, or, more specifically, the marginal effects for real estate fund openings. Because cannibalization is so closely related to our liquidity hypothesis, the two approaches are complementary, and potentially offer important insights.

In our first approach, we propose a novel and direct test of cannibalization. Equation (1) is the base model. The dependent variable measures the net flows into the existing funds of family $i$ within investment objective $j$ during time period $t$. By subtracting net flows into newly opened funds from the total family-objective inflow, we ensure we are measuring cannibalization, and not the overall effect of fund openings. We also use total family-objective inflows as the dependent variable in order to quantify the overall effect of fund openings. For the purpose of our empirical tests, we estimate the following generalized least squares regression model, controlling for panel-specific autocorrelation:

Family-objective inflow measure ij,t $=\alpha_{0}$

$+\beta_{1}$ number of funds opened in the objective $e_{i j, t-1}$

$+\beta_{2}$ family-objective inflow $_{i j, t-1}$

$+\beta_{3}$ family-objective excess return $_{i j, t-1}$

$+\beta_{4}$ family size $\operatorname{sit}_{i, 1}$

$+\beta_{5}$ family assets in objective $(\%)_{i j, t-1}$

$+\beta_{6}$ total number of funds opened ${ }_{i, t-1}$

The explanatory variables include our key variable of interest, the number of funds opened by the family in the respective investment objective (number of funds opened in the objective). This allows us to test whether a cannibalization effect exists. To 
isolate the effect of fund openings on subsequent fund flows, we also control for variables internal to the fund, and, hence, within the fund family's information set. The lagged family-objective inflow controls for possible autocorrelation in the dependent variable. The literature on the flow-performance relationship documents that topperforming mutual funds attract above-average fund flows. Therefore, we include the lagged family-objective excess return as an explanatory variable, and we calculate it as the mean return of all funds of the family within the investment objective in excess of the mean return of all funds of the corresponding investment objective.

We expand the base model by adding a binary variable for funds with a real estate focus and then controlling for the interaction effects of the real estate indicator variable with the number of funds opened in the objective. This enables us to test whether the cannibalization effect differs for real estate fund openings:

Family-objective inflow measure $_{i j, t}=\alpha_{0}+\alpha_{1}$ real estate $_{j}$

$+\beta_{1}$ number of funds opened in the objective ${ }_{i j, t-1}$

$+\beta_{2}$ number of funds opened ij,t-1 $*$ real estate $j$

$+\beta_{3}$ family-objective inflow $_{i j, t-1}$

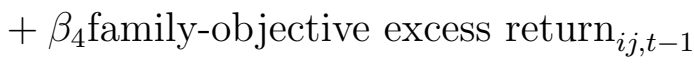

$+\beta_{5}$ family size $_{i, t-1}$

$+\beta_{6}$ family assets in objective $(\%)_{i j, t-1}$

$+\beta_{7}$ total number of funds opened i,t-1

In equations 1 and 2 we also control for the total AuM of the fund family (family size), and the fraction of family assets invested in the corresponding investment objective (family assets in objective (\%)). Finally, we include the total number of funds opened by the family in all investment objectives (total number of funds opened) in order to examine whether a cannibalization effect may arise from fund openings by the family in other investment objectives. ${ }^{6}$ We observe family-objective inflows over

\footnotetext{
${ }^{6}$ We acknowledge that fund fees may also affect fund flows at the family-objective level. A limitation of our data is that information on fees is only available from 2005. As suggested by a referee, we performed an additional analysis where we also control for fees. We calculate a family's average total expense ratio in an investment objective in excess of the overall average in that investment objective.
} 
the 1993-2010 period if a family had funds in existence in a given year and a given investment objective. All asset-based variables are in CPI-deflated constant 2010 Euros. We include year dummies to account for any time effects.

In our second set of tests, we use probit regression models to analyze the determinants of fund openings. The dependent variable is an indicator that measures whether or not fund family $i$ opens a fund in objective $j$ during time period $t$. The explanatory variables consist of internal measures contained in the fund family's information set. The control variables are aggregate industry-level variables.

$$
\begin{aligned}
& \text { Fund opening }{ }_{i j, t}=\alpha_{0}+\alpha_{1} \text { real estate }{ }_{j} \\
& +\beta_{1} \text { family-objective inflow }_{i j, t-1} \\
& +\beta_{2} \text { family-objective inflow }_{i j, t-1} * \text { real } \text { estate }_{j} \\
& +\beta_{3} \text { family size } \text { sitt-1 } \\
& +\beta_{4} \text { family size }_{i, t-1} * \text { real estate }{ }_{j} \\
& +\beta_{5} \text { family assets in objective }(\%)_{i j, t-1} \\
& +\beta_{6} \text { family assets in objective }(\%)_{i j, t-1} * \text { real estate }{ }_{j} \\
& +\beta_{7} \text { total number of funds opened }{ }_{i, t-1} \\
& +\beta_{8} \text { total number of funds opened }{ }_{i, t-1} * \text { real estate }_{j} \\
& +\beta_{9} \text { objective-family excess return }{ }_{i j, t-1} \\
& +\beta_{10} \text { objective-family excess return }{ }_{i j, t-1} * \text { real } \text { estate }_{j} \\
& + \text { control variables }
\end{aligned}
$$

To test analyze the determinants of real estate fund openings relative to all other investment objectives, we interact the explanatory variables (i.e., the internal measures and not the control variables) with the real estate indicator variable. The underlying rationale behind our approach is that we expect potential differences in

As expected, we find that fees are negatively related to family-objective flows. Interestingly, the results on the other variables are qualitatively the same, so we do not include this incomplete variable here because it does not appear to bias our other findings. Similarly, we control for a family's Morningstar rating, which is also available from 2005. We found no significant impact on the dependent variable. After controlling for other variables, we find that a higher average Morningstar rating in an investment objective is not associated with additional inflows into the funds of the family in this investment objective. 
the fund opening determinants between real estate and all other investment objectives to occur from family-specific characteristics such as the potential to compensate for cannibalization or the ability to reap economies of scale and scope. At the same time, we have no reason to believe that broad trends at the aggregate industry level affect the real estate fund opening probability differently than they would for all other investment objectives.

We use family-objective inflow as our liquidity proxy in order to test the liquidity hypothesis of real estate fund openings. This follows because high outflows from existing funds may lead liquidation demand, while high inflows may lead investment demand. We have three proxies for economies of scale and scope in fund openings. First, family size captures scale and scope effects at the fund family level. Since it is well known that specialization can result in scale economies, we also include the family assets in objective (\%) as a proxy for economies of scale and scope. The total number of funds opened in the prior year is included because the fund opening process itself may be subject to economies of scale and scope if fund families learn to innovate more efficiently. Our last variable internal to the fund family is the family-objective excess return, which we include to examine the relationship between fund openings and fund family performance.

Our choice of external control variables is guided by the mutual fund literature. Khorana and Servaes (1999) find that fund opening probability is positively related to the potential to generate additional fee income. This potential is captured by the total size (objective size), and by the aggregate inflows into the investment objective (objective inflow). Khorana and Servaes (1999) also find that more funds are opened in investment objectives that have performed well in the previous year, or where one of the industry leaders has opened a fund in that investment objective. Therefore, we include the variables objective return, which is the mean unadjusted return of all funds within the investment objective, and the indicator variable large family opens, which is equal to one if one of the four largest fund families opens a fund in the respective investment objective. This captures potential industry trends. All assetbased variables are in CPI-deflated constant 2010 Euros. We account for potential family fixed effects by clustering standard errors at the fund family level. In addition, 
year dummies are included to account for any time effects.

\subsection{Comparing the Explanatory Variables for Real Estate with Other Investment Objectives}

Table II contains the descriptive statistics and the distribution of the explanatory variables. We also divide the sample into real estate investment objective (second line), and all other investment objectives (third line). To obtain meaningful values, we calculate family-level statistics if the fund family has at least one fund in the corresponding investment objective. Investment objective-level statistics are calculated if at least one fund exists in the respective investment objective.

In line with the results of Warther (1995), we observe substantial autocorrelation in aggregate fund flows. This is evident for our liquidity measure, family-objective inflow, as well as for the aggregate investment objective (objective inflow). Annual flows into real estate funds, as well as other investment objectives, regularly fall into the negative range. For the real estate funds in our sample, we find outflow values at the fifth percentile of nearly one billion Euros. Given the high persistence in fund flows, this liquidity risk is likely to be a factor in the decision to open a new real estate fund. On the other hand, average inflows of 340 million Euros per year may compensate for potential cannibalization during normal times.

As might be expected, fund families that offer real estate funds are larger on average than families that do not offer real estate funds. Furthermore, real estate fund families are, generally, focused on the real estate investment objective. For example, if real estate funds are offered by a family, they make up an average of $47 \%$ of the family's total AuM. And some fund families are pure real estate specialists. We find no noticeable differences between the overall fund opening activity of families that offer real estate funds and those that do not: Both types average four new funds per year.

Note that the relatively low volatility of the average return of all real estate funds (objective return) is characteristic of real estate as an asset class. Interestingly, we observe strong evidence of persistence in the outperformance of fund families that

offer real estate funds (family-objective excess return). The size of the real estate 
investment objective (objective size) is above average. However, in only $20 \%$ of the years does one of the four largest families in the sample open a real estate fund. This proportion is much higher (i.e., 50\%) in the other investment objectives.

\section{Results}

\subsection{Cannibalization}

Table III contains the generalized least squares regression results of the ex-post effects of fund openings. It is important to note that, in models (i) and (ii), we examine the effect of fund openings by measuring inflows for all funds in the family objective. In contrast, in models (iii) and (iv), we only measure inflows for the funds in the familyobjective that were in existence prior to the opening. This innovation allows us to directly control for the cannibalization effect of fund openings on existing funds (i.e., net of the inflows attributable to the newly opened fund). To this end, we thus adjust family-objective inflows by subtracting flows into new funds. Finally, we interact the number of funds opened with a real estate indicator variable in models (ii) and (iv) to determine whether the effects of fund openings are different for real estate.

The regression results of models (i) and (ii) show the overall effect of fund openings is positive and statistically significant. Based on model (i), each fund opening increases the net inflows of the family within the opened investment objective by an average of 7.4 million Euros in the subsequent year. This overall effect holds for real estate fund openings as well, since the coefficient on the interaction term in model (ii) is not statistically different from zero. Because the number of funds opened also has a positive effect on flows into existing funds, we conclude that "own-product" cannibalization is not an issue.

However, in sharp contrast to the overall effect, we observe substantial cannibalization for real estate fund openings. The coefficient on the interaction term in model (iv) reveals that the marginal effect of real estate fund openings leads to an expected outflow of 475 million Euros from existing real estate funds of the family in the year following the opening. ${ }^{7}$ In isolation, an outflow of this magnitude is likely to cause

\footnotetext{
${ }^{7}$ We thank an anonymous referee for drawing our attention to the possibility that a strong cannibal-
} 
a liquidity crisis for most real estate funds. This suggests that fund families should account for liquidity risk from cannibalization prior to opening another real estate fund. The following analysis reveals under which circumstances this effect may be mitigated.

The strong autocorrelation in family-objective inflows documented in Table II is evident in Table III, even after controlling for several other variables. The result also holds for family-objective flows into existing funds of the family, as seen in models (iii) and (iv). This has important implications for a potential compensation of the cannibalization effect. All else being equal, we expect the cannibalization effect of existing real estate funds to be compensated for when current family-objective inflows are approximately 1.6 standard deviations above average. ${ }^{8}$ However, high outflows are also likely to persist, thus the liquidity risk would be increased further by opening another real estate fund.

Although overall family-objective inflows are unaffected by the size of the fund family, we document a negative relationship between family size and the flow into existing funds. This result might be attributable to more fund openings by larger fund families, which may have stronger marketing campaigns, and can hence draw investor attention to new funds while neglecting existing funds. On the other hand, this effect could also reflect a natural rate of outflows from large and established fund families, which causes them to open new funds in order to maintain market share. We also find that outflows are higher for more specialized fund families.

The coefficient on the total number of funds opened by the family provides ev-

ization effect may result from a limited number of real estate fund options. For example, consider a scenario where investors desire global real estate exposure, but the fund family only offers a fund with European property exposure. When the global fund is opened, investors could switch to the new fund. In a setting where more direct-property fund choices exist, of course, cannibalization may not be as extreme. While we acknowledge this concern, we believe that the small number of real estate fund choices itself is likely to be a result of the cannibalization risk. Figures A1 and A2 in the Appendix show that other countries with real estate fund industries also tend to be characterized by a small number of large real estate funds. This evidence suggests that the German case is representative, and the results are thus generalizable.

8 This approximation is based on the following analysis: $(0.34+\mathrm{x})^{*} 0.253=0.475$. 0.34 is the average family-objective inflow for real estate, as stated in Table II. $\mathrm{x}$ is the amount of above-average flows needed to compensate for the cannibalization effect. The cannibalization effect of 0.475 and the autocorrelation parameter 0.253 come from model (iv) in Table III. x equals 1.54, which is $62 \%$ larger than the standard deviation of real estate family-objective inflows (0.95). 
idence of cross-cannibalization. Flows into a family's investment objective-specific funds are negatively affected by fund openings of the family in other objectives. This could again be attributable to increased marketing efforts for the new funds, while neglecting existing funds in other objectives.

In contrast to what we would expect from the flow performance literature, we find that excess performance does not result in higher inflows. The effect of performance on family-objective inflows is not statistically different from zero. Hence, fund families cannot expect higher inflows as a result of good performance, and performance may be a poor predictor of fund openings.

Overall, the results in Table III confirm certain advantages of fund openings. For example, they lead to an increase in fund flows into the family, which generally comes at little cost to existing fund flows. However, we find a substantial cannibalization effect for real estate fund openings. Thus, we posit that fund families should closely track the flow liquidity of their existing real estate funds when they are considering opening another real estate fund. The results in Table III also suggest that the cannibalization effect may be mitigated when current inflows are high.

\subsection{The Determinants of Real Estate Fund Openings}

Table IV contains the regression results of several specifications concerning the determinants of fund openings. Each model consists of our fund family-specific proxies for liquidity, economies of scale and scope, and returns. The control variables are all comprised of information external to the fund family that aim to capture broader industry trends likely to affect fund opening probability. The specifications differ with respect to which real estate interaction terms are included.

Model (i) is our base specification, which models the fund opening probability in general, without emphasizing real estate-specific differences. In models (ii) to (vi), each explanatory variable that is internal to the fund family is interacted separately with a real estate indicator variable. Model (ii) tests our liquidity hypothesis of real estate fund openings through the interaction term between family-objective inflow and real estate. In models (iii) to (v), each of our three proxies for economies of scale and scope is interacted separately to test our scale and scope hypothesis of real estate 
fund openings. Model (vi) interacts real estate and family-objective excess return, our final measure that is internal to the fund family. This progression enables us to assess each real estate-specific effect individually. The conclusive empirical evidence of our study is based on model (vii), where all interaction terms are included simultaneously.

Because the interpretation of interaction terms in non-linear models is not straightforward, we follow the advice of Greene (2010), and conduct our hypothesis tests based on the statistical significance of the interaction term coefficient, while the economic implications are analyzed graphically. Figures 2, 3, and 4 contrast how the fund opening probabilities for real estate and all other investment objectives change when the explanatory variable of interest is varied over a range of representative values. All other explanatory variables are held constant at their respective subgroup means. The graphical analysis is based on the model (vii) results. The representative values range from 1) the 5th to 95th percentiles, to 2) two standard deviations below and above the mean for real estate fund variables, as reported in Table II.

The regression results of model (i) in Table IV indicate that fund openings are generally not driven by liquidity, as the coefficient on family-objective inflows is not statistically different from zero. This is consistent with the absence of a general cannibalization effect, and the fact that non-real estate funds have fewer problems liquidating portfolio positions in the event of high outflows.

In contrast, the coefficient on the interaction term between real estate and familyobjective inflow in model (ii) is positive and significant. This effect becomes even more pronounced in model (vii), where the coefficient on the interaction term increases from 0.171 to 0.358 .

Figure 2 shows two curves. One is the predicted probability of a new fund opening for real estate as a function of family-objective inflows; the second is for all other asset classes. When the existing real estate funds of the family experience high outflows, the real estate fund opening probability converges to zero. This is intuitive, given that the liquidity risk of existing real estate funds is already above average due to the persistence in outflows, and it would only further increase through the cannibalization effect of a new real estate fund opening.

In contrast, the fund opening probability in all other investment objectives shows 
almost no reaction to outflows of the same magnitude. If outflows are a barrier to real estate fund openings, high inflows can be viewed as a necessary (although not sufficient) condition for real estate fund openings because they attenuate the cannibalization effect. In fact, the real estate fund opening probability surpasses that of fund openings in other investment objectives during times of high inflows. Consequently, we find evidence in support of the liquidity hypothesis of real estate fund openings.

Next, we examine fund opening probability and economies of scale and scope. The positive and statistically significant coefficient for family size in model (i) implies fund opening probability is positively related to fund family size. This is consistent with the theory that large fund families reap economies of scale and scope by opening more funds. However, this effect is significantly less pronounced for real estate fund openings, as indicated by the negative sign of the coefficient on the interaction term between real estate and family size in models (iii) and (vii). Nevertheless, real estate fund opening probability increases with fund family size. While a one-standard deviation increase in family size raises the probability in all other investment objectives by $6.9 \%$, real estate fund openings become only $1.9 \%$ more likely.

Figure 3 illustrates the comparative insensitivity of the real estate fund opening probability to our proxy for economies of scale and scope. This finding is consistent with the hypothesis that fund families do not reap economies of scale and scope by opening more real estate funds, and they thus have incentives to allow existing real estate funds to grow large.

Specialization is another well-known source of scale economies. In general, fund families tend to specialize their products when opening new funds. This is evident in model (i) by the positive coefficient on the fraction of family assets invested in an investment objective (\%). This may be attributable to the fact that the performancerelated advantages of fund openings, as outlined in section 2, are most likely to be achieved when new fund openings are concentrated in one investment objective. The coefficient on the interaction term between family assets invested in an investment objective (\%) and real estate is negative, although insignificant in model (iv). However, after controlling for further real estate-specific effects in model (vii), the relation 
is significant, with a t-statistic of -2.23 . Note this does not mean fund families do not specialize in real estate. It merely suggests that real estate fund openings are a comparatively weak tool to achieve specialization gains.

For example, as we have noted, the strategy of opening new funds in order to generate a higher likelihood of a star performer is risky in the case of real estate because of cannibalization risk and high transaction costs. Therefore, fund families that open a new real estate fund may be more interested in the extension of their product line than in other considerations. Figure 4 illustrates this relationship graphically.

The number of funds opened in the prior year is our third proxy for economies of scale and scope in fund openings. A positive relationship would indicate scale and scope economies in the process of launching new funds. The coefficient on the number of funds opened is positive and statistically significant in model (i). This suggests that fund families with more experience in opening new funds are in a better position to transfer that knowledge and the associated efficiencies to additional fund openings.

However, scale and scope economies in the fund opening process do not seem to be transferable or applicable to real estate. We observe that the main effect in model (i) is not only reduced for real estate, it is neutralized. The interaction or marginal effect is significantly negative in model (v). But a joint test of the linear combination of funds opened and the interaction term with real estate in model (vii) reveals that the effect of the number of funds opened on the real estate fund opening probability is not statistically different from zero. ${ }^{9}$ This result provides further evidence that scale and scope economies are not a driver of real estate fund openings. One explanation is that the process of launching a real estate fund has little in common with the opening of a fund that invests in other assets.

We next analyze the relationship between fund opening probability and the performance of existing funds within a family's investment objective. A negative relationship would support the "window-dressing" argument of fund openings. Our results show no significance for the family-objective excess return in model (i), and no statistically significant difference for real estate in models (vi) and (vii). Thus,

\footnotetext{
${ }^{9}$ Family size and the number of funds opened are highly correlated $(\mathrm{p}=0.61)$, so we suspect these variables mask each other. This is likely the reason why the interaction effect of the number of funds opened becomes insignificant in model (vii).
} 
we find no evidence that fund families try to window dress the poor performance of existing funds by opening new funds.

The results on the investment objective-level control variables are robust across all models. We find that fund opening probability is positively related with aggregate flows into and the size of the investment objective. Both variables capture the potential to generate fee income in the market, so this result supports the view that maximizing fee income is an important motive for fund openings. We find no significant relationship between the prior returns of an investment objective and the respective fund opening probability in that investment objective. Thus, fund families do not appear to chase returns in their decision to open a new fund, but they do follow industry leaders. The fund opening probability significantly increases if one of the four largest fund families in our sample opens a fund in that investment objective.

In additional robustness tests, we investigate whether real estate fund openings are driven by a family's return forecasts. We use an event study setting, and find that real estate fund openings tend to occur as the average return of existing real estate funds increases relative to the risk-free rate. We observe a 1.5-percentage point increase in the excess return of real estate funds in the months prior to a fund opening. This suggests that fund families tend to open new real estate funds in environments where real estate returns have become increasingly attractive. However, this effect is not statistically significant in our econometric framework. ${ }^{10}$

As a final caveat, our findings are predicated on the generalizability of results obtained from historical data for the German mutual fund industry. Due to the small number of real estate fund openings, this may not be the ideal setting in which to study the determinants of fund openings and, in general, cannibalization effects. We acknowledge this potential concern, nonetheless we believe Germany is the best setting in which to study these issues in a real estate context.

Of course, one must always be careful when generalizing results across borders. This is particularly true in a setting with a relatively small number of real estate fund openings. However, the global overview of real estate fund markets in the Appendix confirms Germany's status as a leader in this industry, with the largest and most

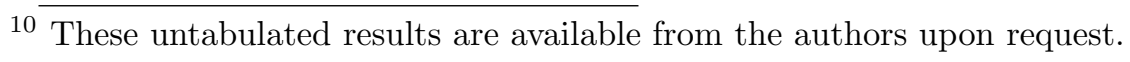


developed market for open-end, direct-property real estate funds available to retail (individual) investors.

As Figure A2 in the Appendix shows, the large size and small number of real estate funds compared to other fund types is the rule rather than the exception on a global scale. Thus, the cannibalization of fund flows due to new openings increases the liquidity risk for all types of real estate investment vehicles with an open-end structure. Likewise, and given the fact that there are virtually no differences between global mutual fund industries, the absence of a cannibalization effect in all other investment objectives seems intuitive and anecdotally obvious.

A similar argument can be made for closed-end real estate funds. Liquidity, in the form of high capital inflows, mitigates the cannibalization effect, and would seem to increase the probability of achieving minimum subscription amounts. Independent of real estate investment vehicle type, direct-property portfolios benefit from economies of scale and scope. This, of course, gives fund families an incentive to let existing funds grow large before new real estate funds are opened. Furthermore, fund families that offer investment products in diverse asset classes are less likely to benefit from economies of scope through real estate fund openings. This is most likely not the case for fund openings within and across the classical asset classes or investment objectives (i.e., stocks, bonds, and money market).

\section{Conclusion}

This paper examines fund flow cannibalization and the determinants of fund openings, with an emphasis on real estate. Drawing on a unique dataset and institutional detail of the German mutual fund industry over the 1992-2010 period, we analyze 2,127 fund openings within 12 investment objectives for 76 fund families.

The decision to open a new fund is essentially a cost-benefit trade-off for managers. Our results indicate that this trade-off generally favors new openings for funds that invest in liquid asset classes. We find that fund flow cannibalization is not an issue for these funds. At the same time, we find evidence of economies of scale and scope through fund openings. Thus, fund openings are a relatively low-risk, high-reward 
strategy that appeals to fund families seeking to capitalize on the advantages they can offer. Our results are consistent with Khorana and Servaes (2012), who find that fund openings lead to higher market share. We also show that fund openings lead to increased fund flows, which is beneficial for the AuM and fee income of fund families.

Our main contribution comes from examining the contrasts evident in real estate fund openings. Here, we find new openings are significantly less beneficial to fund families. We document a substantial cannibalization effect, which is of even greater concern (i.e., potentially costly) due to the illiquid nature of real estate as an underlying assets. Our results illustrate that high liquidity (i.e., high inflows into existing real estate funds) is the key factor in overcoming the cannibalization barrier. Furthermore, we find that real estate fund openings are not sensitive to our proxies for family-level economies of scale and scope. This result is consistent with strong fundlevel economies of scale that provide the incentive to let existing real estate funds grow large. Together with the cannibalization result, the lack of scale and scope economies implies that opening a new real estate fund can be a high-risk, low-reward strategy for fund families.

We conclude by reminding readers that the real estate funds we examine are not perfect. We caution readers - whether academics, fund families, investors, or regulators - to remember there is "no free lunch: diversification and lower volatility through an investment in private real estate comes at the price of less liquidity" (Esrig, Kolasa, and Cerreta, 2013).

At the same time, the benefits and appeal of real estate funds are recognized globally. During the period following our sample construction, Morningstar reported 48 newly opened real estate funds with the global category used for our study - i.e., "property-direct." And as recently reported in France, "retail open-end real estate funds are finally taking off." 11

Our paper does not specifically address the risk-return characteristics of directproperty investment, or the benefits of real estate-related diversification in a multiasset portfolio. Recent and global evidence on that topic is easily accessible elsewhere:

11 See http://www.pie-mag.com/articles/6523/french-retail-opci-funds-finally-take-off-in-2012/. For clarification, we point out that the term "retail" in this article title refers to "the general public" (e.g., individual or retail investors), as opposed to the retail property type. 
See MacKinnon and Al Zaman (2009) and Rehring (2012) for examples.

On the other hand, our research contributes to the literature by examining the factors and trade-offs associated with the launch of new funds, specifically, those devoted to an underlying asset that is inherently illiquid in an open-end format that preserves the risk-return characteristics of a direct-property investment. The continued evolution of this investment vehicle as a form of financial intermediation, and the industrial organization of the markets in which new funds are formed, is a topic of ongoing interest in the U.S. and abroad. ${ }^{12}$

12 See Esrig, Kolasa, and Cerreta (2013) for a discussion of how defined contribution retirement planning - obviously, a changing landscape - may benefit from open-end, direct-property funds. 


\section{References}

Ambrose, B. W., M. J. Highfield, and P. D. Linneman (2005). Real estate and economies of scale: The case of REITs. Real Estate Economics 33(2), 323-350.

Berzins, J. (2005). Do families matter in institutional money management industry: The case of new portfolio openings. SSRN Scholarly Paper ID 811209, Social Science Research Network, Rochester, NY.

Bodie, Z., A. Kane, and A. J. Marcus (2011). Investments. McGraw-Hill/Irwin.

Boudry, W. I., J. G. Kallberg, and C. H. Liu (2010). An analysis of REIT security issuance decisions. Real Estate Economics 38(1), 91-120.

Chen, J., H. Hong, M. Huang, and J. D. Kubik (2004). Does fund size erode mutual fund performance? The role of liquidity and organization. American Economic Review 94(5), 1276-1302.

Cooper, M. J., H. Gulen, and P. R. Rau (2005). Changing names with style: Mutual fund name changes and their effects on fund flows. Journal of Finance 60(6), 2825-2858.

Deli, D. N. (2002). Mutual fund advisory contracts: An empirical investigation. Journal of Finance 57(1), 109-133.

Eichholtz, P., K. Koedijk, and M. Schweitzer (2001). Global property investment and the costs of international diversification. Journal of International Money and Finance 20(3), 349-366.

Esrig, D., S. Kolasa, and L. Cerreta (2013). Assessing the impact of real estate on target date fund performance. Journal of Portfolio Management, Special Real Estate Issue (2013), 144-155.

Evans, R. B. (2010). Mutual fund incubation. Journal of Finance 65(4), 1581-1611.

Focke, C. (2006). The development of german open-ended real estate funds. Journal of Real Estate Literature 14(1), 39-56. 
Goetzmann, W. N. and R. G. Ibbotson (1993). Games mutual fund companies play: Strategic response to investor beliefs in the mutual fund industry. Working paper, Yale School of Management.

Greene, W. (2010). Testing hypotheses about interaction terms in nonlinear models. Economics Letters 107(2), 291-296.

Khorana, A. and H. Servaes (1999). The determinants of mutual fund starts. Review of Financial Studies 12(5), 1043-1074.

Khorana, A. and H. Servaes (2012). What drives market share in the mutual fund industry? Review of Finance 16(1), 81-113.

Khorana, A., H. Servaes, and P. Tufano (2005). Explaining the size of the mutual fund industry around the world. Journal of Financial Economics 78(1), 145-185.

Khorana, A., H. Servaes, and P. Tufano (2009). Mutual fund fees around the world. Review of Financial Studies 22(3), 1279-1310.

Latzko, D. A. (1999). Economies of scale in mutual fund administration. Journal of Financial Research 22, 331-340.

MacKinnon, G. H. and A. Al Zaman (2009). Real estate for the long term: The effect of return predictability on long-horizon allocations. Real Estate Economics 37(1), $117-153$.

Massa, M. (2000). Why so many mutual funds? Mutual fund families, market segmentation and financial performance. SSRN Scholarly Paper ID 239851, Social Science Research Network, Rochester, NY.

Massa, M. (2003). How do family strategies affect fund performance? When performance-maximization is not the only game in town. Journal of Financial Economics 67(2), 249-304.

Nanda, V., Z. J. Wang, and L. Zheng (2004). Family values and the star phenomenon: Strategies of mutual fund families. Review of Financial Studies 17(3), 667-698. 
Nanda, V. K., Z. J. Wang, and L. Zheng (2009). The ABCs of mutual funds: On the introduction of multiple share classes. Journal of Financial Intermediation 18(3), 329-361.

Plazzi, A., W. Torous, and R. Valkanov (2008). The cross-sectional dispersion of commercial real estate returns and rent growth: Time variation and economic fluctuations. Real Estate Economics 36(3), 403-439.

Plazzi, A., W. Torous, and R. Valkanov (2010). Expected returns and expected growth in rents of commercial real estate. Review of Financial Studies 23(9), 3469-3519.

Rehring, C. (2012). Real estate in a mixed-asset portfolio: The role of the investment horizon. Real Estate Economics 40(1), 65-95.

Schweizer, D., L. H. Haß, L. Johanning, and B. Rudolph (2011). Do alternative real estate investment vehicles add value to REITs? evidence from german open-ended property funds. Journal of Real Estate Finance and Economics 47(1), 65-82.

Sirri, E. R. and P. Tufano (1998). Costly search and mutual fund flows. Journal of Finance 53(5), 1589-1622.

Warther, V. A. (1995). Aggregate mutual fund flows and security returns. Journal of Financial Economics 39(2-3), 209-235.

Weistroffer, C. and S. Sebastian (2014). The german open-end fund crisis - a valuation problem? Journal of Real Estate Finance and Economics, 1-32.

Zhao, X. (2004). Why are some mutual funds closed to new investors? Journal of Banking EJ Finance 28(8), 1867-1887.

Zhao, X. (2005). Entry decisions by mutual fund families. Stock Exchanges, IPO's and Mutual Funds, Nova Science Publishers, Inc., New York, 151-179. 


\section{Appendix}

The German mutual fund industry shares many similarities with mutual fund industries around the world. As Khorana, Servaes, and Tufano (2005) state, "There is a recognizable mutual fund 'style' of intermediation in most countries, characterized by a transparent investment vehicle whose underlying assets are identifiable with the value of the fund marked-to-market on a regular (usually daily) basis and reflected in the NAV of the fund with new shares created or redeemed upon demand."

A mutual fund of the type described above is an open-end investment company. ${ }^{13}$ Bodie, Kane, and Marcus (2011) define investment companies as "financial intermediaries that collect funds from individual investors and invest those funds in a potentially wide range of securities or other assets." We add the emphasis on "other assets" (i.e., not securities), as our study focuses on open-end funds where the underlying investments are real assets (i.e., private market properties).

The underlying assets of German real estate funds - and their counterparts around the world - are direct-property investments along with cash or other liquid securities. ${ }^{14}$ Note, for example, that the top five holdings of the German fund Grundbesitz Global are all office properties - the largest one is in China, two are in the U.K., and two are in the U.S. The fact that open-end, direct-property mutual funds are available to retail investors through the German mutual fund industry is a key point of differentiation with the U.S. experience. In 2010, Morningstar reported 174 open-end funds in the global category "property-direct." None of these funds was U.S.-domiciled.

Figure A1 shows the number of funds and total net assets for open-end, directproperty funds available to retail investors across countries with significant real estate fund markets. For the U.S., where there is no comparable market for retail investors, we use institutional open-end real estate funds reported by NCREIF to illustrate the point. Although the institutional details of open-end, direct-property funds for retail investors vary somewhat across countries, Germany is the world leader, with 102.4

13 The term "mutual fund" is common nomenclature for an investment company that pools assets to be invested by a fund manager. In contrast to hedge funds or private equity funds, which are less regulated because they are typically structured as private partnerships, mutual funds are sold to the general public.

14 The first description of the German version of this investment vehicle published in a U.S.-based real estate journal is Focke (2006). 
billion USD in assets, and a total of 28 funds.

Given the relative illiquidity of real estate as an underlying asset, the issues of pricing, fund-level liquidity, and fees are of particular interest in an open-end fund format. German real estate funds report NAV daily, based on the market value of cash and liquid securities, as well as on appraisal-based property value. Properties are valued by independent appraisers annually or more frequently, based on a staggered schedule. Consequently, a real estate fund's entire portfolio is revalued on at least an annual basis. The NAV-based pricing scheme results in a risk-return profile that is comparable to the NCREIF private real estate indices.

Several mechanisms aim to support fund-level liquidity. These include high cash reserves. The regulated minimum cash reserve for German real estate funds is $5 \%$; the average is approximately 30\%, which is considerably higher than the cash holdings of equity and other investment objective funds. The fee structure also helps to mitigate fund-level liquidity shocks. Front-end loads of $5 \%$ are remarkably consistent across German real estate funds and across time. Average total expense ratios (TERs) for German real estate funds in 2010 were $0.97 \%$, compared to $1.44 \%$ for other investment objectives within the German mutual fund industry.

Surprisingly, back-end loads are not assessed on German real estate funds. While the front-end load might dissuade short-term trading, it is not a deterrent to fundlevel liquidity shocks due to redemptions. In July 2013, two years after the end of our sample period, the legislature introduced additional mechanisms to support fund-level liquidity. These measures include minimum holding periods of 24 months, as well as a 12-month announcement period for the redemption of shares.

Fund-level liquidity may also benefit from the size of German open-end, direct property funds. Figure A2 illustrates one of our stylized facts: Real estate funds (specifically, the open-end, direct property funds that are the subject of this analysis) are on average larger than funds dedicated to other investment objectives. 
Figure A1: Countries with significant open-end real estate fund markets

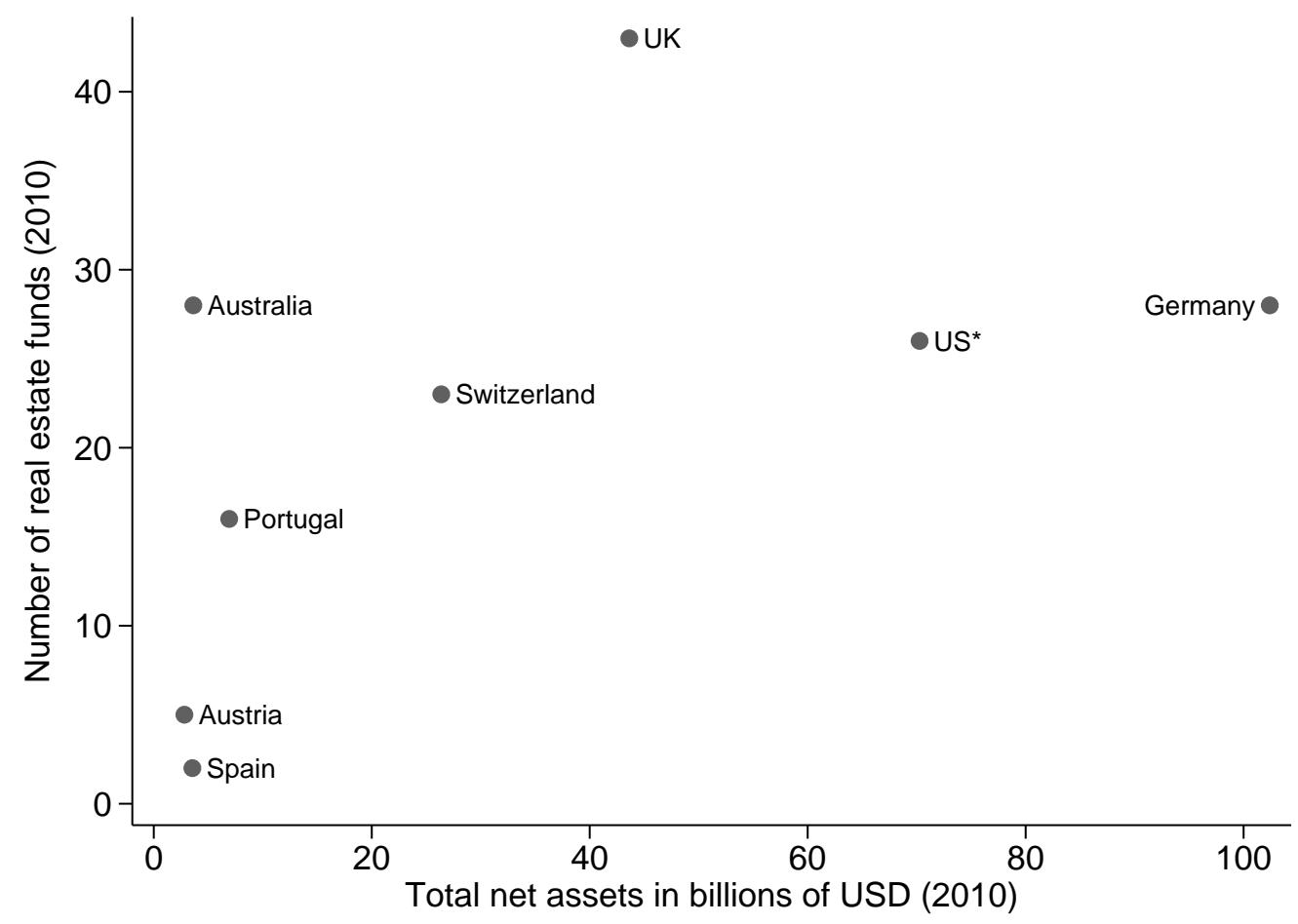

This figure shows the number of open-end real estate funds and the total net asset value of all real estate funds in a given country in billions of USD for 2010. The figure includes countries with open-end real estate fund industries in excess of one billion USD. We identified the countries by filtering open-end funds in Morningstar with the global category "property-direct" ("For the U.S., we considered commingled real estate funds that are included in the NFI-OE (NCREIF Fund Index - Open End Equity). Data on the four largest markets are carefully supplemented with countryspecific data. Data on German open-end real estate funds (offene Publikumsfonds) are based on the BVI Investmentstatistik. Data on U.K. open-end property unit trusts that are accessible to retail investors are obtained from the AREF/IPD Property Fund Vision Handbook. For Switzerland, we consider all Swiss real estate funds. 
Figure A2: Average fund size of open-end real estate funds compared to other asset classes

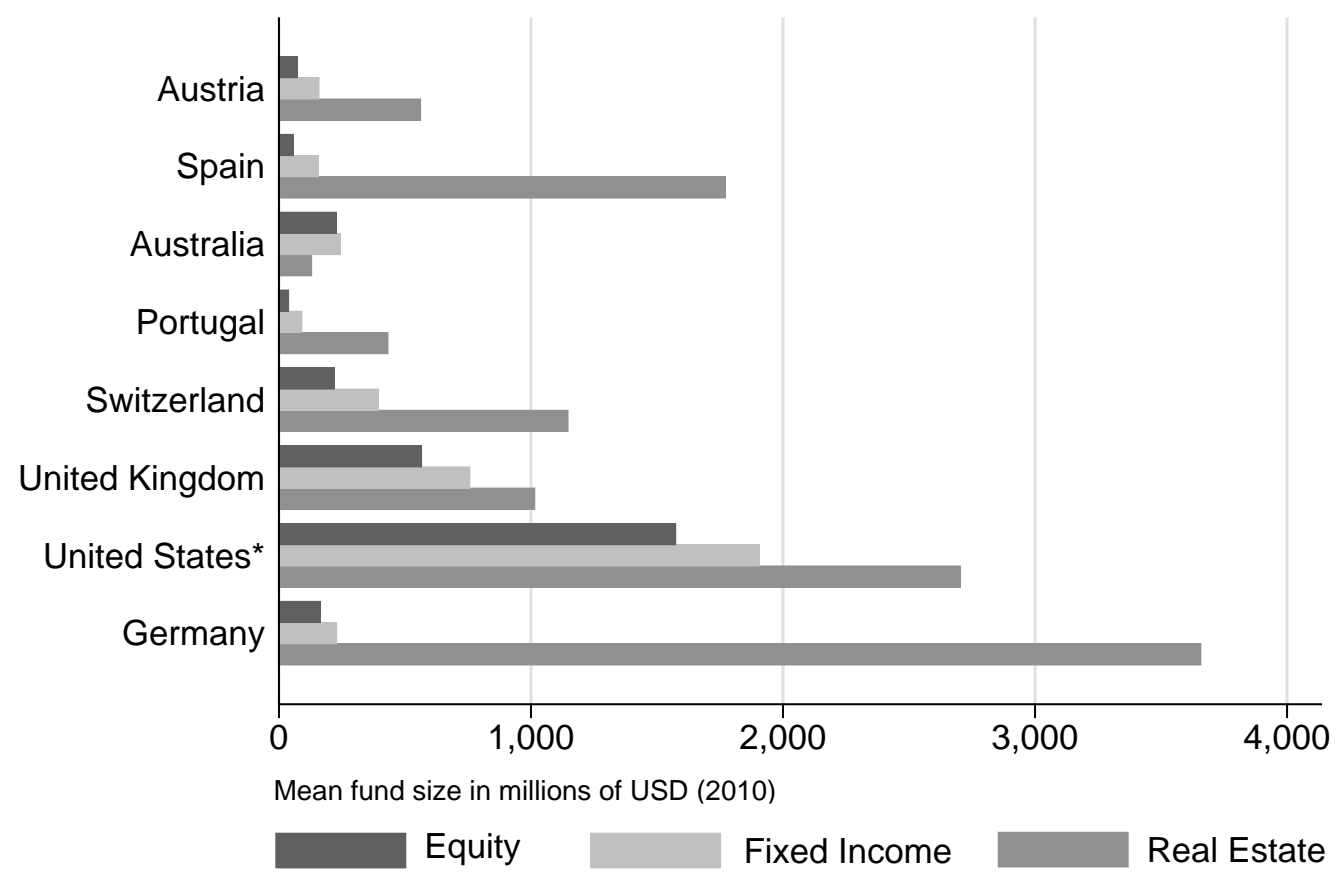

This figure compares the mean fund size of real estate, fixed income, and equity funds in millions of USD for 2010. The figure includes countries with open-end real estate fund industries in excess of one billion USD. The countries are ordered, top to bottom, based on total NAV, as shown in Figure A1. We identified the countries by filtering open-end funds in Morningstar with the global category "property-direct" ( ${ }^{*}$ For the U.S., we considered commingled real estate funds that are included in the NFI-OE (NCREIF Fund Index - Open End Equity). Data on the four largest markets are carefully supplemented with country-specific data. Data on German open-end real estate funds (offene Publikumsfonds) are based on the BVI Investmentstatistik. Data on U.K. open-end property unit trusts that are accessible to retail investors are obtained from the AREF/IPD Property Fund Vision Handbook. For Switzerland, we consider all Swiss real estate funds. 
Figure 1: Fund openings, total AuM and average fund size

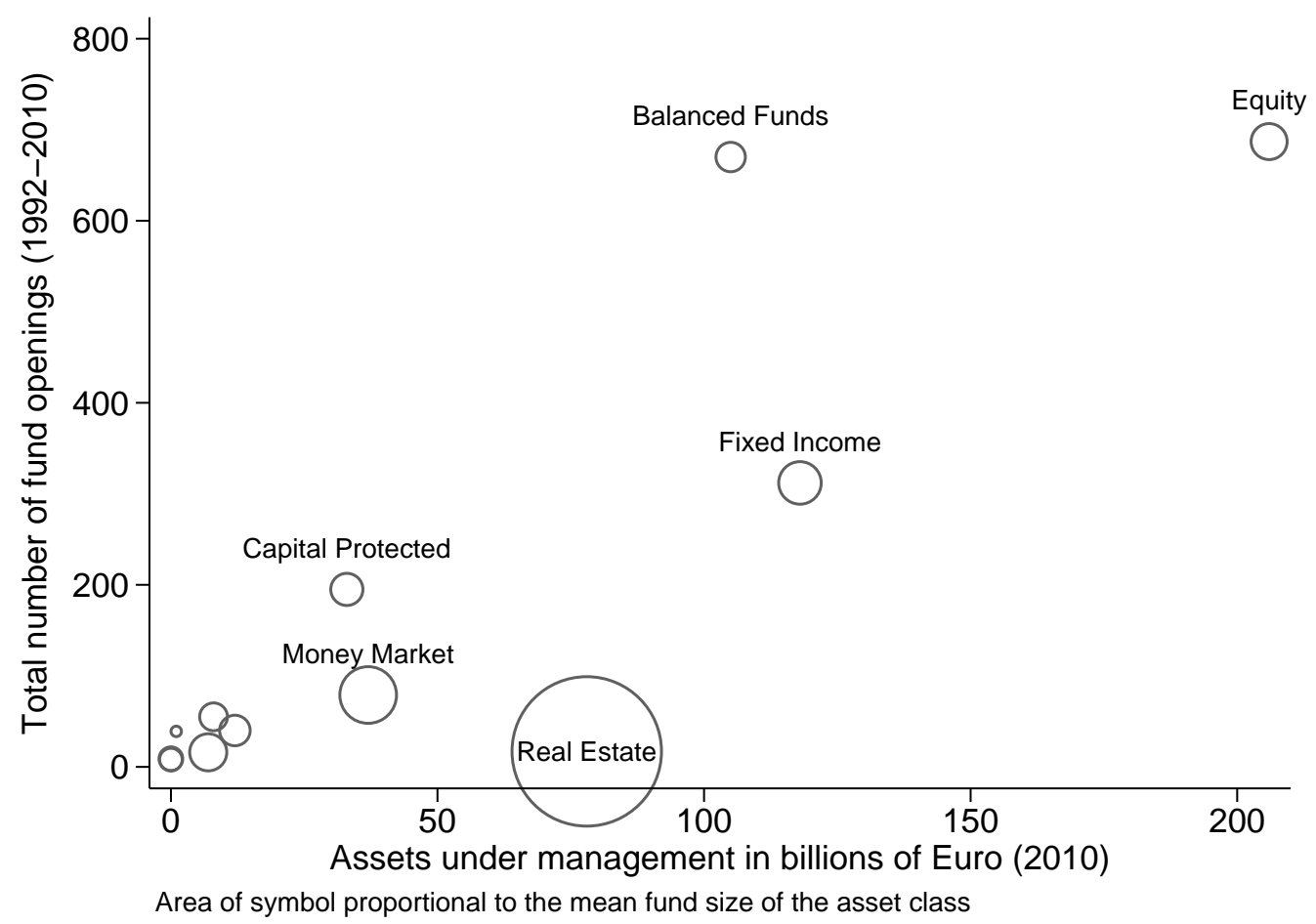

This figure shows the relation between the total number of fund openings between 1992 and 2010, and the size of the investment objective (AuM in billions Euros). The bubble, or circle, areas are proportional to the average fund size $(\mathrm{AuM})$ within the respective investment objective. 
Figure 2: Effects of family-objective inflows on fund opening probability

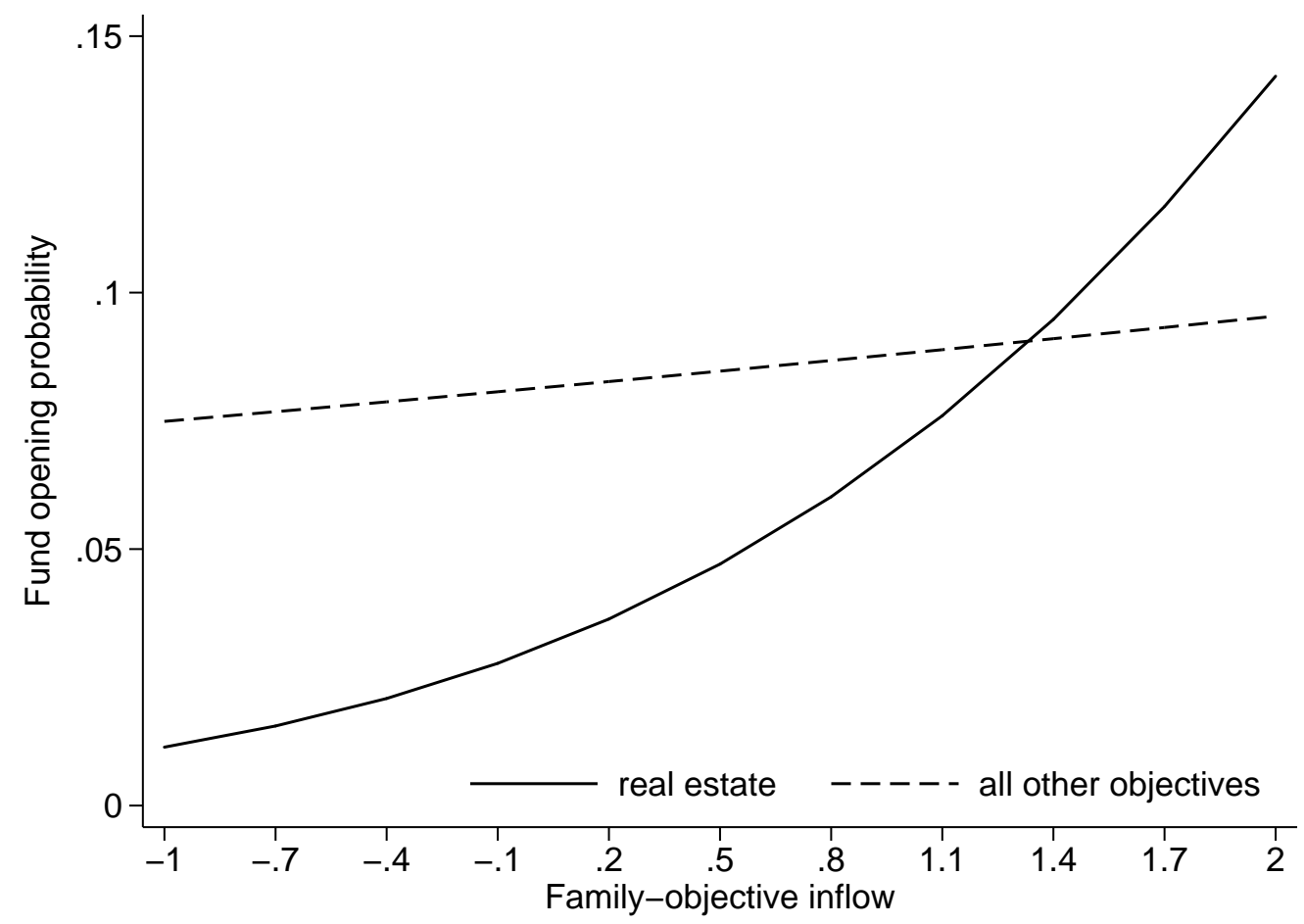

This figure compares how fund opening probabilities react to changes in the liquidity measure familyobjective inflow. Family-objective inflow is measured in billions of Euros, and is varied over the range of representative values for fund families with existing real estate funds. The other explanatory variables are fixed at their respective subgroup means, as reported in Table II. 
Figure 3: Effects of family size on fund opening probability

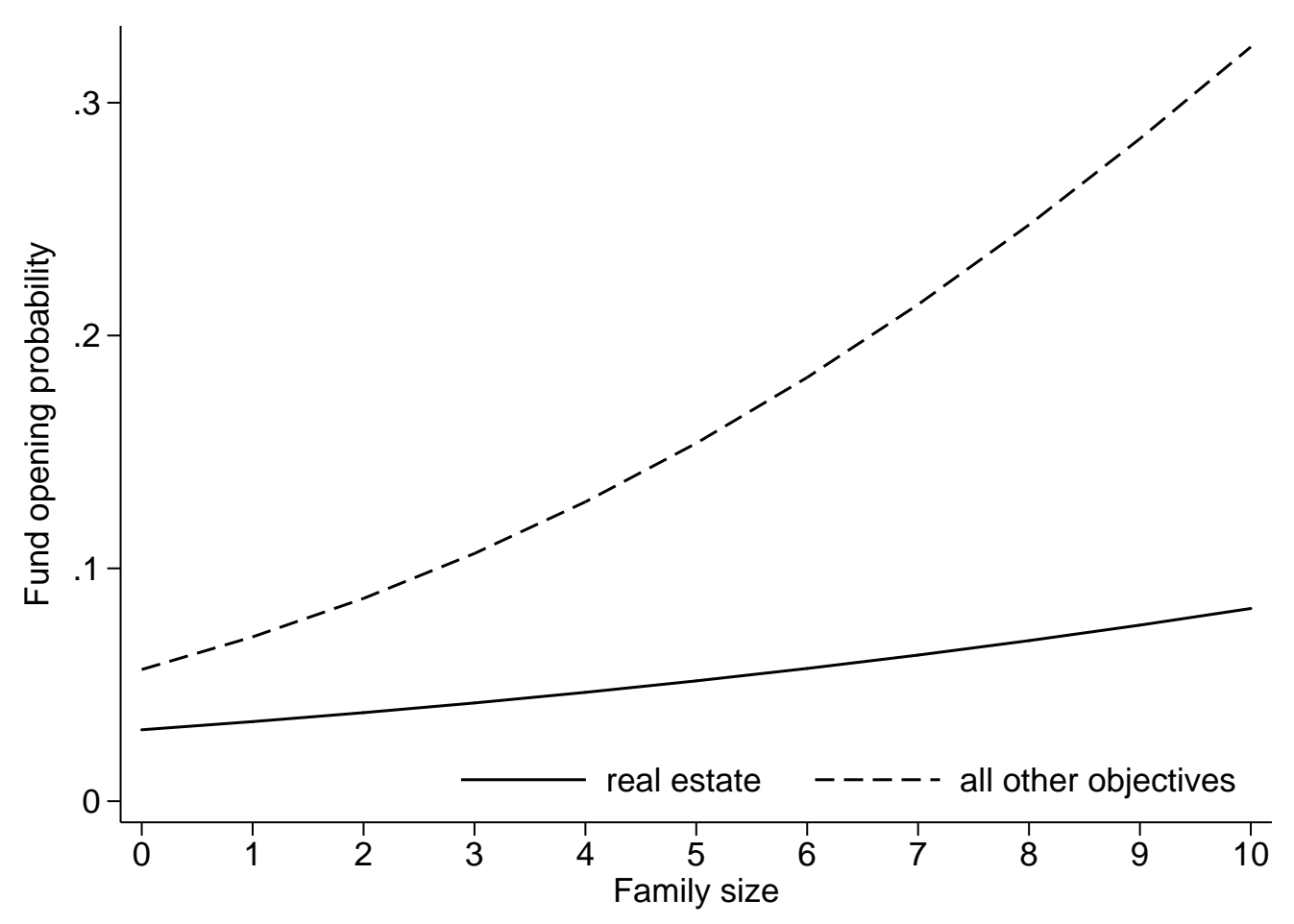

This figure compares how fund opening probabilities react to changes in the economies of scale and scope measure family size. Family size is measured in 10 billion Euros, and is varied over the range of representative values for fund families with existing real estate funds. The other explanatory variables are fixed at their respective subgroup means, as reported in Table II. 
Figure 4: Effects of family assets in an investment objective on the fund opening probability

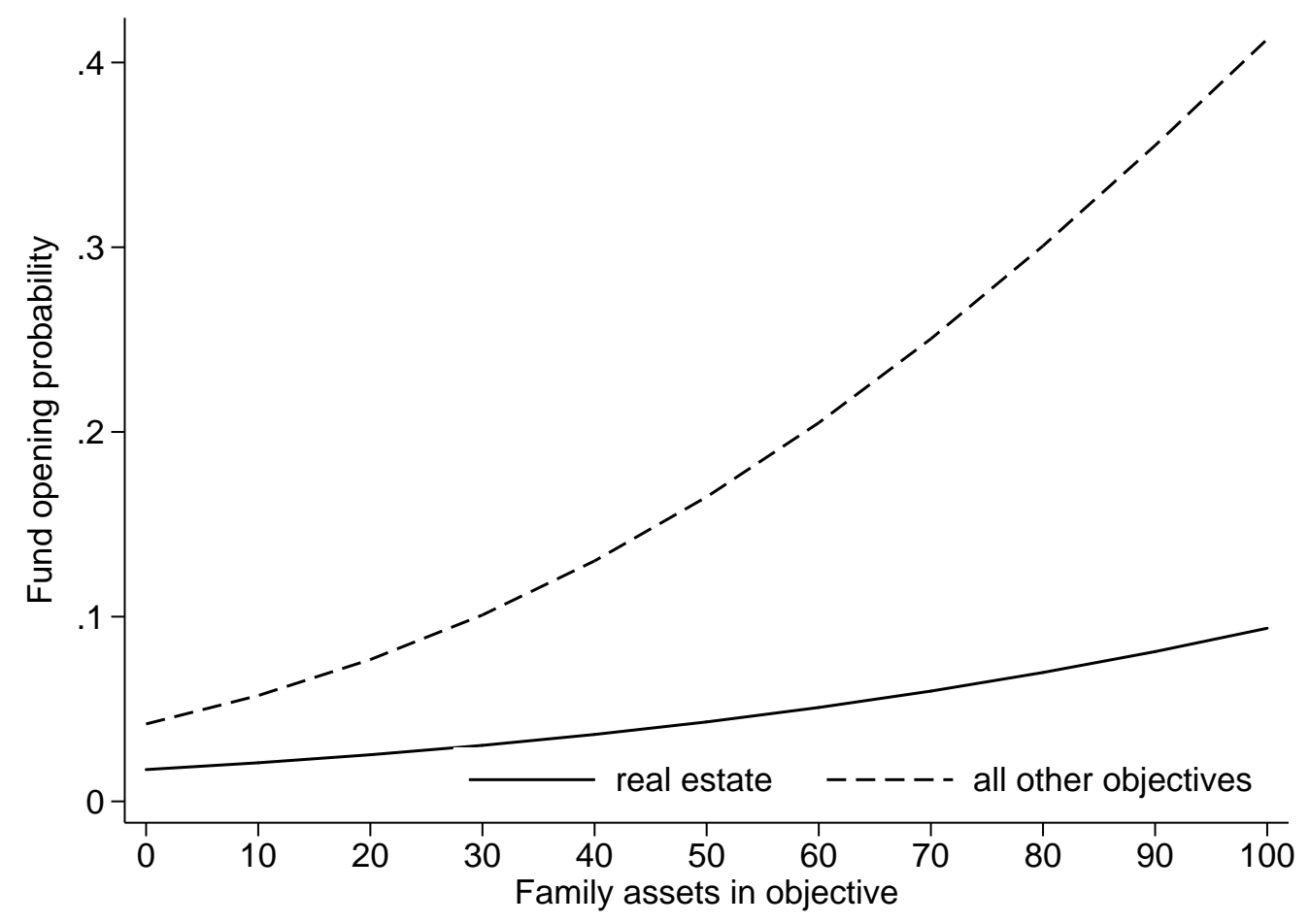

This figure compares how fund opening probabilities react to changes in the economies of scale and scope measure family assets in objective. Family assets in objective is measured in (\%), and is varied over the range of representative values for fund families with existing real estate funds. The other explanatory variables are fixed at their respective subgroup means, as reported in Table II. 


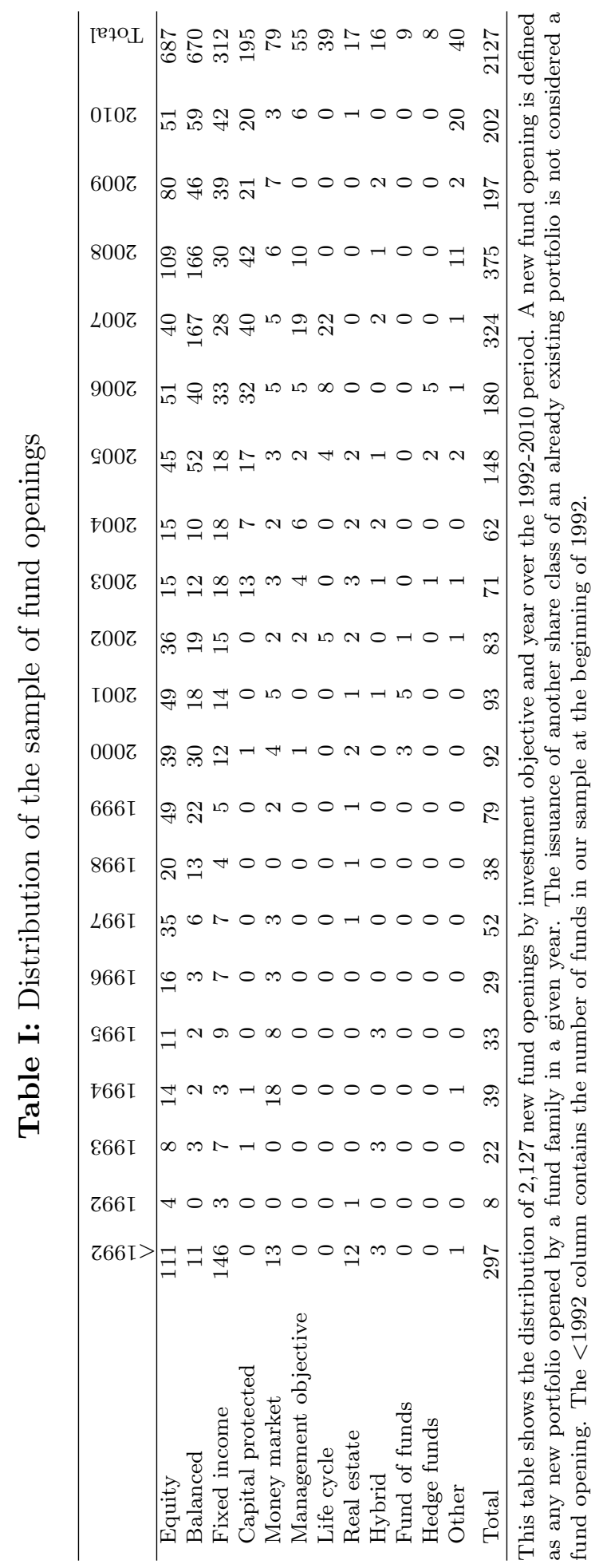


Table II: Distribution of the explanatory variables

\begin{tabular}{|c|c|c|c|c|c|c|c|}
\hline & \multicolumn{2}{|c|}{ Standard } & \multicolumn{3}{|c|}{ Percentile } & \multicolumn{2}{|c|}{ Autocorrelation } \\
\hline & Mean & Deviation & 5 th & Median & 95th & $\operatorname{AR}(1)$ & T-statistic \\
\hline Family-objective inflow & 0.05 & 0.99 & -0.59 & 0.00 & 0.90 & $0.40^{* * *}$ & 25.48 \\
\hline Real estate objective & 0.34 & 0.95 & -0.95 & 0.16 & 1.97 & $0.38^{* * *}$ & 6.23 \\
\hline All other objectives & 0.03 & 0.99 & -0.55 & 0.00 & 0.63 & $0.40^{* * *}$ & 24.38 \\
\hline Family size (total assets) & 17.47 & 33.59 & 0.15 & 2.64 & 108.80 & $1.02^{* * *}$ & 328.17 \\
\hline Real estate objective & 27.43 & 38.70 & 0.47 & 6.72 & 113.30 & $1.02^{* * *}$ & 77.90 \\
\hline All other objectives & 16.76 & 33.09 & 0.14 & 2.44 & 10.88 & $1.02^{* * *}$ & 318.49 \\
\hline Family assets in objective (\%) & 23.83 & 25.56 & 0.30 & 15.20 & 81.05 & $0.88^{* * *}$ & 113.31 \\
\hline Real estate objective & 47.28 & 35.36 & 7.46 & 30.00 & 100.00 & $0.90^{* * *}$ & 32.05 \\
\hline All other objectives & 22.14 & 23.84 & 0.27 & 14.27 & 74.47 & $0.87^{* * *}$ & 103.54 \\
\hline Total number of funds opened & 4.06 & 7.89 & 0 & 1 & 18 & $0.80^{* * *}$ & 68.84 \\
\hline Real estate objective & 4.02 & 8.44 & 0 & 1 & 20 & $0.82^{* * *}$ & 19.29 \\
\hline All other objectives & 4.07 & 7.85 & 0 & 1 & 18 & $0.80^{* * *}$ & 66.04 \\
\hline Family-objective excess return & -0.10 & 5.35 & -7.95 & 0.00 & 7.32 & $0.03^{*}$ & 1.71 \\
\hline Real estate objective & -0.02 & 3.32 & -2.94 & 0.22 & 4.14 & $0.85^{* * *}$ & 8.19 \\
\hline All other objectives & -0.10 & 5.46 & -8.07 & 0.00 & 7.69 & 0.02 & 1.27 \\
\hline Objective size(total assets) & 41.68 & 55.85 & 0.10 & 9.84 & 156.89 & $0.98^{* * *}$ & 410.27 \\
\hline Real estate objective & 60.37 & 25.03 & 16.19 & 61.10 & 93.99 & $0.88^{* * *}$ & 135.20 \\
\hline All other objectives & 39.63 & 57.89 & 0.09 & 6.72 & 159.82 & $0.98^{* * *}$ & 387.04 \\
\hline Objective inflow & 0.86 & 7.66 & -10.91 & 0.03 & 11.55 & $0.44^{* * *}$ & 57.93 \\
\hline Real estate objective & 4.19 & 5.84 & -6.29 & 3.84 & 15.77 & $0.31^{* * *}$ & 12.16 \\
\hline All other objectives & 0.49 & 7.75 & -11.25 & 0.02 & 11.17 & $0.44^{* * *}$ & 54.18 \\
\hline Objective return (\%) & 3.60 & 10.66 & -16.59 & 4.43 & 19.62 & -0.00 & -0.13 \\
\hline Real estate objective & 4.68 & 2.53 & -0.52 & 4.60 & 8.88 & $0.88^{* * *}$ & 36.22 \\
\hline All other objectives & 3.48 & 11.20 & -16.82 & 4.30 & 19.63 & -0.00 & -0.55 \\
\hline Large family opens & 0.53 & 0.50 & 0 & 1 & 1 & $0.43^{* * *}$ & 58.03 \\
\hline Real estate objective & 0.20 & 0.40 & 0 & 0 & 1 & $-0.27 * * *$ & -10.51 \\
\hline All other objectives & 0.57 & 0.50 & 0 & 1 & 1 & $0.45^{* * *}$ & 58.80 \\
\hline
\end{tabular}

This table shows the distribution of the annual values of the explanatory variables over the 1991-2010 period. All asset-based variables are measured in CPI-deflated constant year 2010 billions of Euros. The statistics of the investment objective-level variables objective inflow, objective size, objective return and large family opens are calculated if the respective investment objective was in existence at that time. We calculate family-level variables family-objective inflow, family-objective excess return, family assets in objective, family size, and total number of funds opened if the family was invested in the respective investment objective. The second number shows the subsample statistics for the real estate investment objective. The third number shows the respective values for all other asset classes. Parameters marked with $* * *, * *$, and ${ }^{*}$ are significant at the 1 
Table III: Fund openings and fund flows

\begin{tabular}{|c|c|c|c|c|}
\hline & \multicolumn{2}{|c|}{$\begin{array}{l}\text { Family-objective inflow } \\
\text { (All Funds) }\end{array}$} & \multicolumn{2}{|c|}{$\begin{array}{l}\text { Family-objective inflow } \\
\text { (Only Existing Funds) }\end{array}$} \\
\hline & Model (i) & Model (ii) & Model (iii) & Model (iv) \\
\hline Number of funds opened in the objective ${ }_{t-1}$ & $\begin{array}{c}0.074^{* * *} \\
(8.66)\end{array}$ & $\begin{array}{c}0.078^{* * *} \\
(9.03)\end{array}$ & $\begin{array}{c}0.031^{* * *} \\
(4.20)\end{array}$ & $\begin{array}{c}0.037^{* * *} \\
(4.90)\end{array}$ \\
\hline Number of funds opened in the objective $t-1 * r e$ & $\begin{array}{l}- \\
-\end{array}$ & $\begin{array}{l}0.118 \\
(0.53)\end{array}$ & $\begin{array}{l}- \\
-\end{array}$ & $\begin{array}{c}-0.475^{* *} \\
(-2.43)\end{array}$ \\
\hline Family-objective inflow $t-1$ & $\begin{array}{c}0.368^{* * *} \\
(22.85)\end{array}$ & $\begin{array}{c}0.364^{* * *} \\
(22.60)\end{array}$ & $\begin{array}{c}0.259 * * * \\
(18.34)\end{array}$ & $\begin{array}{c}0.253^{* * * *} \\
(18.00)\end{array}$ \\
\hline Family size (total assets) $t-1$ & $\begin{array}{l}0.004 \\
(0.61)\end{array}$ & $\begin{array}{l}-0.001 \\
(-0.14)\end{array}$ & $\begin{array}{c}-0.019 * * * \\
(-3.40)\end{array}$ & $\begin{array}{c}-0.025^{* * *} \\
(-4.46)\end{array}$ \\
\hline Family assets in objective $(\%)_{t-1}$ & $\begin{array}{c}-0.002^{* * *} \\
(-3.43)\end{array}$ & $\begin{array}{c}-0.003^{* * *} \\
(-4.75)\end{array}$ & $\begin{array}{c}-0.002^{* * *} \\
(-4.72)\end{array}$ & $\begin{array}{c}-0.004^{* * *} \\
(-6.15)\end{array}$ \\
\hline Total number of funds opened $t-1$ & $\begin{array}{c}-0.013 * * * \\
(-4.06)\end{array}$ & $\begin{array}{c}-0.012^{* * *} \\
(-4.08)\end{array}$ & $\begin{array}{c}-0.009^{* * *} \\
(-3.22)\end{array}$ & $\begin{array}{c}-0.009 * * * \\
(-3.16)\end{array}$ \\
\hline Family-objective excess return ${ }_{t-1}$ & $\begin{array}{l}0.004 \\
(1.46)\end{array}$ & $\begin{array}{l}0.004 \\
(1.50)\end{array}$ & $\begin{array}{l}0.003 \\
(1.43)\end{array}$ & $\begin{array}{l}0.003 \\
(1.44)\end{array}$ \\
\hline Real estate (re) & $\begin{array}{l}- \\
-\end{array}$ & $\begin{array}{c}0.328^{* * *} \\
(4.81)\end{array}$ & $\begin{array}{l}- \\
-\end{array}$ & $\begin{array}{c}0.440^{* * *} \\
(7.18)\end{array}$ \\
\hline Constant & $\begin{array}{c}0.102^{* *} \\
(2.01)\end{array}$ & $\begin{array}{l}0.087 \\
(1.62)\end{array}$ & $\begin{array}{c}0.166^{* * *} \\
(3.69)\end{array}$ & $\begin{array}{c}0.139^{* * *} \\
(2.82)\end{array}$ \\
\hline Wald $C h i^{2}$ & 725.37 & 769.55 & 475.06 & 539.40 \\
\hline Prob $>C h i^{2}$ & 0.0000 & 0.0000 & 0.0000 & 0.0000 \\
\hline Observations & 3580 & 3580 & 3580 & 3580 \\
\hline
\end{tabular}

This table contains the generalized least squares (GLS) regression results for the ex-post effects of fund openings. The unit of observation is the fund family investment objective-year. The dependent variables in models (i) and (ii) are flows into all funds of the family in a given investment objective that year. This allows us to study the overall effect of fund openings. In models (iii) and (iv), flows into existing funds of the family exclude flows into funds opened the previous year. This allows us to isolate and study the cannibalization effect of fund openings. Explanatory variables are the number of funds opened by the family in the given investment objective, asset inflows into the investment objective within the family, average excess return of the funds of the family in the investment objective, total size of the fund family, fraction of all family assets invested in the investment objective, and total number of funds opened by the family in any investment objective. Models (ii) and (iv) control for real estate-specific differences in the effects of fund openings through the inclusion of a real estate indicator variable, and an interaction term of the real estate indicator variable with the number of funds opened by the family in the given investment objective. We estimate the model by controlling for panel-specific autocorrelation. All asset-based variables are in CPI-deflated 2010 constant Euros. T-statistics are in parentheses. Coefficients marked with ***,**, and * are significant at the $1 \%, 5 \%$, and $10 \%$ levels, respectively. Wald $C h i^{2}$ is the Wald Chi-Square statistic, used to test the hypothesis that at least one of the predictors' regression coefficients is not equal to zero. Prob $>C h i^{2}$ is the probability of getting a Wald test statistic as extreme as the observed statistic under the null hypothesis that all the regression coefficients are equal to zero. 


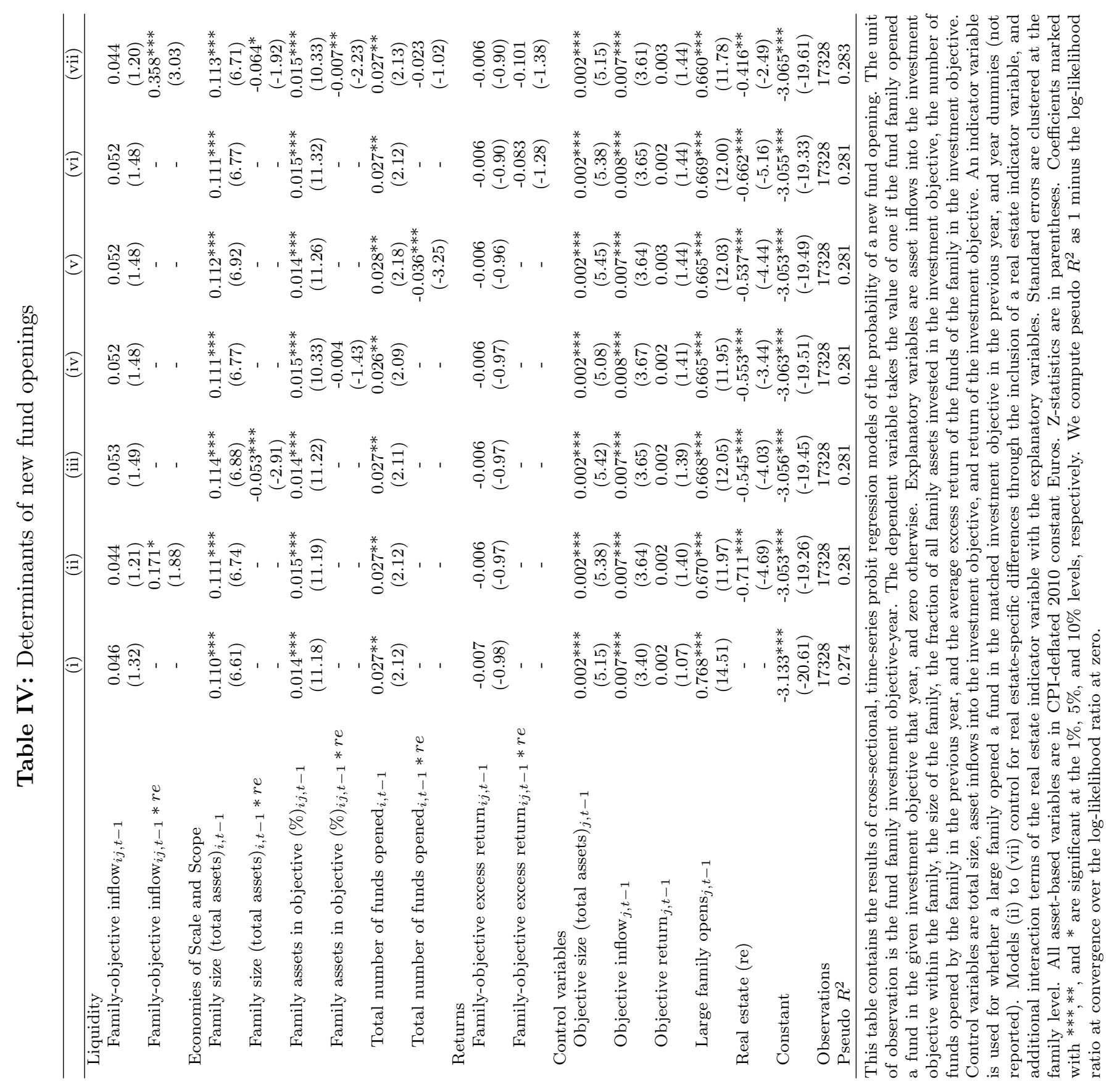

